\title{
Orthopaedics and Traumatology in COVID-19 Pandemic
}

\author{
COVID-19 Pandemisinde Ortopedi ve Travmatoloji
}

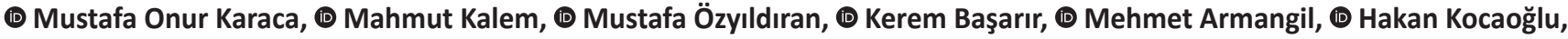

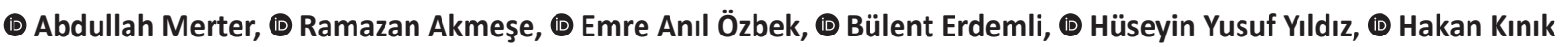 \\ Ankara University Faculty of Medicine, Department of Orthopedics and Traumatology, Ankara, Turkey
}

\section{Abstract}

Objectives: We aimed to convey our pandemic observations and experience as orthopedics and traumatology clinic in the period from the formal declaration of the first case in Turkey to the descending trend of the number of active cases.

Materials and Methods: The first Coronovirus disease-2019 (COVID-19) case in Turkey was seen on March 11 and all elective surgeries were postponed as of March $17^{\text {th }}$. The number of active cases entered a downward trend with the number of patients recovering daily exceeding the number of new cases daily on April 24. The numbers and categories of surgeries performed in our clinic between March 17 and April 24, 2020 were examined and analyzed by comparing to the same period of 2019.

Results: A total of 105 surgical operations were performed in our clinic between March 17 and April 24, 2020. Of these operations, 33.3\% were trauma, 25.7\% were hand and finger injury, and 14.3\% were orthopedic oncology cases. During the same period of 2019, a total of 436 operations were performed, of which 19.3\% were trauma, 16.5\% were arthroscopy, 12.6\% were arthroplasty, 11.9\% were hand and finger injuries, and 8.9\% were oncological surgery cases. It was seen that the number of surgeries decreased by $76 \%$ during the pandemic.

Conclusion: The COVID-19 pandemic has profoundly affected daily life and work practice in the field of orthopedics and traumatology. It is important to create an administrative organizational chart during crisis periods like a pandemic and to implement the measures to be taken immediately.

Key Words: COVID-19, Elective Orthopedic Surgery, Emergent and Urgent Orthopedic Surgeries, Personal Protective Equipment, PCR

\section{$\ddot{O z z}$}

Amaç: Türkiye'de ilk olgunun resmi olarak ilan edilmesinden aktif olgu sayısının iniş trendine geçmesine kadarki süreçte, ortopedi ve travmatoloji kliniği olarak pandemi gözlem ve tecrübelerimizin aktarılması amaçlanmıştır.

Gereç ve Yöntem: Türkiye'de ilk Koronavirüs Hastalığı-2019 (COViD-19) olgusu 11 Mart tarihinde görülmüş, 17 Mart itibariyle tüm elektif ameliyatlar ertelenmiştir. 24 Nisan 2020 tarihinde günlük iyileşen hasta sayısının günlük yeni olgu sayısını geçmesiyle birlikte, aktif olgu sayısı iniş trendine geçmiştir. 17 Mart - 24 Nisan 2020 tarihleri arasında kliniğimizde uygulanan ameliyat sayıları ve kategorileri incelenmiş, 2019 yılının aynı periyodu ile mukayese edilerek analiz edilmiştir. Pandemi sürecinde hastanemizde ve bölümümüzde alınan önlemler incelenmiştir. Elektif olguların iptal edilmesiyle birlikte oluşan yeni ameliyathane düzeni ve öncelik algoritmaları değerlendirilmiştir. Pandemi sürecinde preoperatif ve postoperatif olarak servisimizde COViD-19 tanısı alan hastaların tedavi yönetimi incelenmiştir.

Bulgular: 17 Mart - 24 Nisan 2020 tarihleri arasında kliniğimizde toplam 105 ameliyat uygulanmıştır. Bu ameliyatların \%33,3'ü travma, \%25,7'si el ve parmak yaralanması, \%14,3'ü ise ortopedik onkoloji olgularıdır. 2019 yılının aynı periyodunda 436 ameliyat uygulanmış olup bunların \%19,3'ü travma, \%16,5'i artroskopi, \%12,6'sı artroplasti, \%11,9'u el ve parmak yaralanmaları, \%8,9'u onkolojik cerrahi olgularıdır. Pandemi sürecinde ameliyat sayısının \%76 oranında düştüğü görülmektedir.

Sonuç: COViD-19 pandemisi ortopedi ve travmatoloji camiasının günlük hayatını ve çalışma pratiğini derinden etkilemiştir. Pandemi gibi kriz dönemlerinde yönetimsel organizasyon şemasının oluşturulması ve vakit kaybetmeden alınacak önlemlerin uygulanması önem arz etmektedir. Anahtar Kelimeler: COViD-19, Elektif Ortopedik Cerrahi, Acil Ortopedik Cerrahi, Kişisel Koruyucu Ekipman, PCR

Address for Correspondence/Yazışma Adresi: Mustafa Özyıldıran,

Ankara University Faculty of Medicine, Department of Orthopedics and Traumatology, Ankara, Turkey

Phone: +90 3125082321 E-mail: mozyildiran@gmail.com ORCID ID: orcid.org/0000-0002-2187-9267

Received/Geliş Tarihi: 22.10.2020 Accepted/Kabul Tarihi: 27.12.2020

๑Copyright 2021 Ankara University Faculty of Medicine

Journal of Ankara University Faculty of Medicine is published by Galenos Publishing House.

All content are under CC BY-NC-ND license. 


\section{Introduction}

The first case of severe acute respiratory syndrome coronavirus-2 (SARS-CoV-2) infection was reported in Wuhan, China in December 2019, and named as Coronavirus disease-2019 (COVID-19) by the World Health Organization (WHO) $(1,2)$. The outbreak of COVID-19 was announced by the WHO as a pandemic on March 11 (3). The first case of COVID-19 in Turkey was officially reported by the Ministry of Health on March 11. As of March 17, elective surgical procedures were postponed throughout Turkey with the writing by the Directorate General of Health Services of the Ministry of Health titled "Postponement of Elective Procedures and Other Measures to be taken". On March 20, hospitals with $3^{\text {rd }}$ step adult intensive care beds and all private hospitals were declared to be "pandemic hospitals" (4). A rapid increase was seen in the number of cases throughout Turkey since March 11, when the first case appeared, and the number of cases reached 104,912 on April 24 (4). The number of active cases entered a downward trend with the number of patients recovering daily exceeding the number of new cases daily on April 24, 2020 (Figure 1).

In this article, we aim to convey our pandemic experience and observations as the department of orthopedics and traumatology in the period from March 11, when the first cases seen in Turkey, until April 24.

\section{Materials and Methods}

The numbers and categories of surgeries performed in our clinic between March 17 and April 24, 2020 were examined and analyzed by being compared with the same period of 2019. The measures taken in our hospital during the pandemic process were examined. The new operating room layout and priority algorithms that were formed with the cancellation of elective cases were evaluated. The treatment management of patients diagnosed with COVID-19 in our service preoperatively and postoperatively during the pandemic process was examined.
The study protocol received Institutional Review Board approval (No: i7-428-20).

\section{Results}

\section{COVID-19 Measures in Faculty of Medicine}

After the hospitals of our university were declared as a "pandemic hospital", a "pandemic action plan commission" was established and administrative plans were made for COVID-19 (5). In the first stage, elective medical and interventional procedures were postponed. With this practice, it was aimed to prevent the individuals who applied to the hospital for elective procedures from being affected by the epidemic.

Necessary spatial arrangements were made in the emergency ward and outpatient clinics so that patients admitted to the hospital with the suspicion of COVID-19 could be evaluated separately from other patients. Departments and intensive care units were planned, where possible cases would be hospitalized. Our hospital consists of 15 floors and in the first stage, $1^{\text {st }}$, $2^{\text {nd }}$, and $4^{\text {th }}$ floors were planned as COVID wards. The $3^{\text {rd }}$ floor was kept ready to be converted into the intensive care unit when needed. Most of the patients in other departments were discharged and the evacuated patient rooms were kept ready for use when needed. The rooms were converted into single rooms.

Physicians in all departments of the hospital were assigned to work in the established COVID wards and outpatient clinics in the order determined by the hospital management voluntarily. In-hospital training meetings were held by the infection control committee. The hospital staff was informed about the use of personal protective equipment (standart mask, N95 mask, gloves, glasses, surgical apron, jumpsuit).

During the pandemic, visitor access was restricted to protect the health of patients and their relatives. The training of the trainee and intern physicians in the hospital was interrupted and the distance education model was introduced during this process.

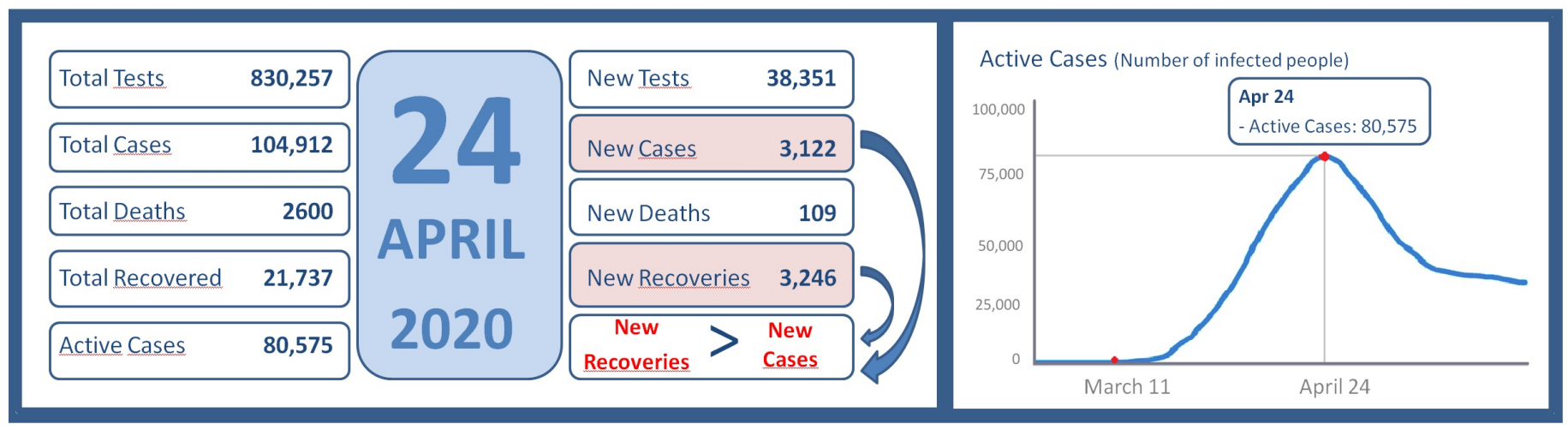

Figure 1: Turkey coronavirus case chart. The data is obtained from the official website of the Ministry of Health (3) and tabulated by the authors. 


\section{COVID-19 Measures in the Orthopedics and Traumatology Department}

Elective surgical operations were postponed and the patients whose treatments were completed were discharged immediately. The orthopedics and traumatology department consisted of 3 blocks. There were 13 single-bed rooms, 6 2-bed rooms, 4 3-bed rooms and 5 4-bed rooms in the department, and 57 patient beds in total. During the pandemic, all rooms were converted into single rooms in line with the recommendations of the infection control committee and the bed capacity was reduced to 28. The rooms of the patients, who were discharged after their treatments were completed, were left empty for use in case of a possible need.

Department doctors, nurses, and staff participated in the training organized by the infection control committee. Sufficient personal protective equipment was provided for use in the department.

Like other department physicians, orthopedics and traumatology residents were subject to rotation in COVID services and returned to the orthopedics and traumatology department after two weeks of isolation.

During the pandemic, assistant training classes and weekly councils were interrupted, and assistant courses and case presentations were held via distance learning.

\section{COVID Measures and Applications in the Operating Room}

Spatial arrangements were made in the operating room and separate operation rooms with negative pressure were determined, in which COVID positive patients would be operated. Waiting times in the premedication unit were reduced and patients were less likely to contact each other before surgery. The training for the operating room staff, nurses, anesthesia technicians, and anesthesia team were given by the infection committee.

Preoperatively, all patients were evaluated for COVID with the symptoms of high fever, cough, and shortness of breath, inquiry of contact history, and detailed physical examination. The patients were evaluated in terms of COVID in the emergency department and the hospitalization ward and evaluated preoperatively by anesthesiologists. All patients were preoperatively referred to the department of infectious diseases with suspicion of COVID, and a polymerase chain reaction (PCR) test was performed by taking a nasopharyngeal/oropharyngeal swab sample. The patients were classified as positive, suspicious, or negative for COVID following the examinations performed. Under this classification, algorithms for personal protective equipment to be used during surgery were created (Figure 2). In emergency cases where it could not be waited for the PCR results, patients were considered COVID positive and taken to operation.

During transportation from the ward to the operating room, the patient is put on a medical mask. To reduce contact, the patient is brought to the room after all preparations are completed in the operating room. The anesthesiologist completes the preparation of the anesthesia device before the patient is brought in the room, and the nurse prepares the surgery sets. During the anesthesia procedure, no one other than the anesthesia team is in the room, and the door of the room is kept closed during the procedure. Depending on the type of procedure to be performed and the general condition of the patient, spinal anesthesia, or peripheral nerve blocks are preferred. If the patient is to be intubated, the anesthesia team uses protective glasses and an N95 mask. Similar precautions are also considered when the patient is awakened and during transport to the ward.

\section{Emergent and Urgent Orthopaedic Surgeries}

In the pandemic period, elective surgical procedures were delayed to later dates. By reducing the number of hospital admissions, it was aimed to reduce the spread of infection. In addition, with this application, it was aimed to prevent medical material and equipment problems that might occur during the

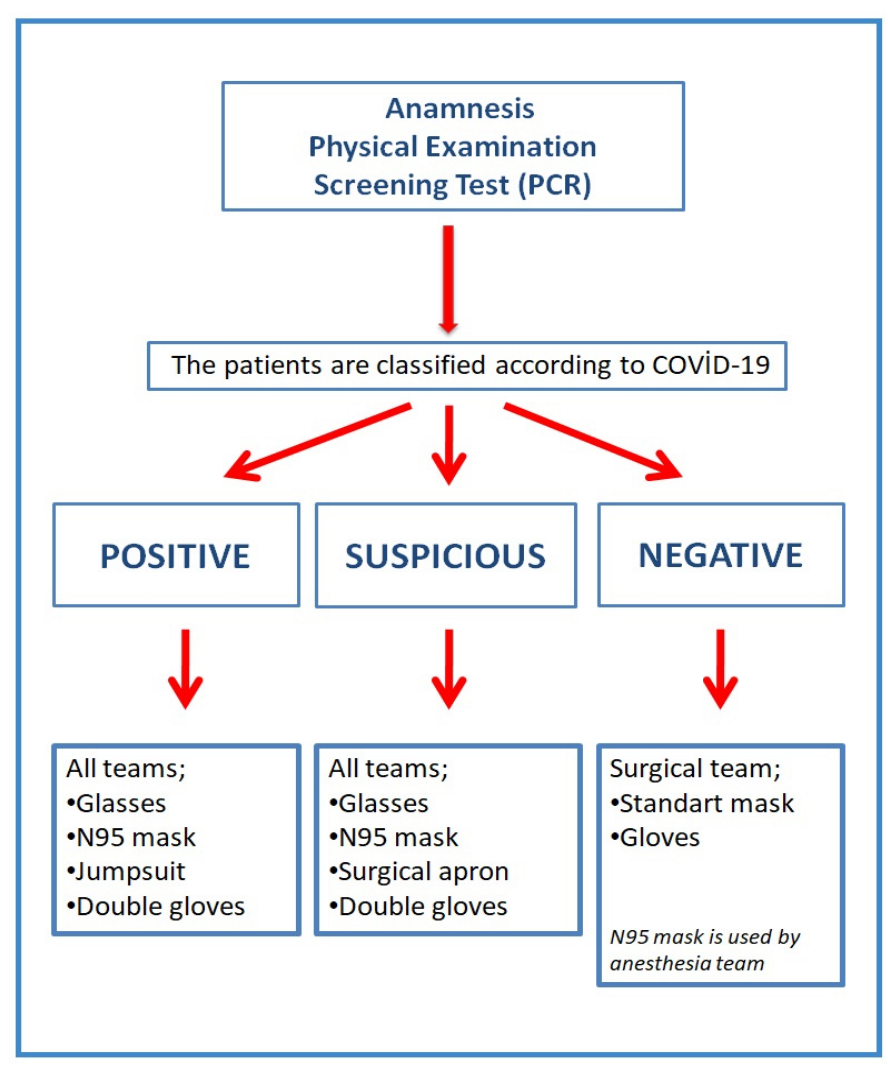

Figure 2: Personal protective equipment to be used in the operating room

PCR: Polymerase chain reaction, COVID-19: Coronavirus disease-2019 
pandemic process. Since March 17, 2020, elective cases across Turkey were postponed to a later date but which operations were "elective" was not described clearly. The classification we used in our clinic regarding the urgency of orthopedic surgical procedures was summarized in Table 1.

Cases such as replantation, compartment syndrome, septic arthritis, joint and prosthetic dislocation, open fracture, pelvic fractures in which hemodynamic stability was impaired were considered as "emergent" surgical cases. In emergent cases, patients were accepted as possible COVID positive cases and operated without waiting for the results of preoperative screening tests for COVID. In the postoperative period, patients were evaluated for COVID and screening tests were performed.

Closed fractures, hand and finger injuries where circulation is preserved, prosthesis infection, and oncological cases were accepted as "urgent" surgical cases. Urgent cases were preoperatively evaluated for COVID by being referred to the department of infectious diseases. The patients were classified as positive/suspicious/negative in terms of COVID by routine evaluation consisting of anamnesis, physical examination, and PCR test. The operations of positive and suspicious patients were carried out under the operating room layout using the necessary personal protective equipment.

Procedures such as arthroscopic surgeries (shoulder, wrist, knee, hip), scoliosis surgery, and primary arthroplasty were accepted as "elective cases" and postponed to later dates. Apart from the hemiarthroplasty procedures for the femoral neck fracture, primary arthroplasty surgery was not performed due to arthrosis.

\section{Analysis of Orthopedic Surgeries between March 17 and} April 24

A total of 105 surgeries were performed in our clinic between the dates of March 17, 2020, when elective cases were postponed, and April 24, 2020, when the number of active cases entered a downward trend (Figure 3). Of these surgical operations, 33.3\% were for trauma, $25.7 \%$ for hand and finger injuries, and $14.3 \%$ for orthopedic oncology cases. In this period, elective procedures such as arthroscopy, primary arthroplasty, scoliosis surgery were not performed in our clinic. During the same period of 2019, a total of 436 surgeries were performed, of which 19.3\% were for trauma, 16.5\% for arthroscopy, 12.6\% for arthroplasty, $11.9 \%$ for hand and finger injuries, and $8.9 \%$ for oncological surgery cases (Table 2). It was seen that the number of surgeries decreased by $76 \%$ during the pandemic process. The cancellation of elective cases was the most important factor in this decline. A decrease was also observed in the number of trauma cases, and lockdown restrictions applied due to the pandemic might be effective in this case.

When the numbers of patients referred to our department from adult and child emergency departments were examined, it was seen that a total of 174 patients were sent for consultation between 17 March 2020 and 24 April 2020, with 105 patients from the adult emergency department, and 69 patients from the pediatric emergency department. During the same period of 2019, a total of 451 patients, 235 from the adult emergency department, and 216 from the pediatric emergency department were sent for consultation (Table 3). A decrease of 61.5\% was seen in the total number of patients referred to our department

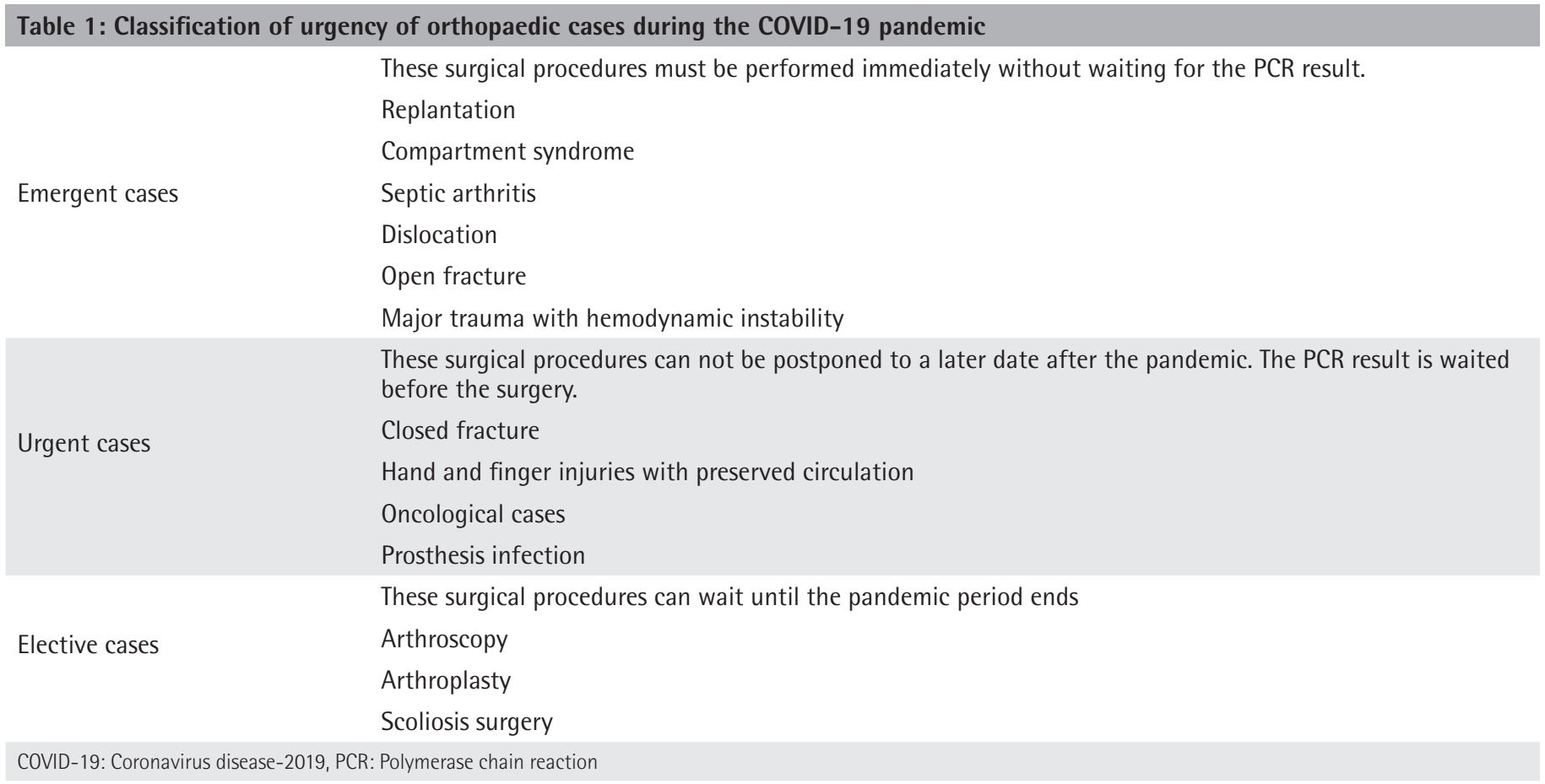


Number of

TRAUMA:

Femur neck fracture

Intertrochanteric fracture

Trimalleolar fracture

Supracondylar humerus fracture

Tibia diaphyseal fracture

Subtrochanteric fracture

Periprosthetic fracture of the femur

Both bone forearm fracture

Tibial plateau fracture

Proximal humerus fracture

Syndesmosis injury

Distal radius fracture

Calcaneus fracture

HAND AND FINGER INJURIES

Zone 2 flexor injury

Zone 5 flexor injury

Phalanx fracture

Metacarpal fracture

Finger amputation; replantation

Finger amputation; stump repairment

Nail bed injury

Zone 2 extensor injury

ORTHOPAEDIC ONCOLOGY

Pathological femoral shaft fracture

Distal femur osteosarcoma

Distal femur osteochondroma

Ewing sarcoma

(iliac crest, distal femur, scapula)

Malign mesenchymal tumor

(pelvis, sacrum, thigh, suprascapular region)

Pelvic chondrosarcoma

Closed biopsy

Open biopsy

OTHERS

Debridement

Septic arthritis

Diabetic foot, amputation

Vertebral compression fracture

Spinal stenosis

Revisions of external fixators (ilizarov, LRS)

Removal of the epiphysiodesis plate

Skin graft application

Extensor foot injury, extensor tendon repair
Cases

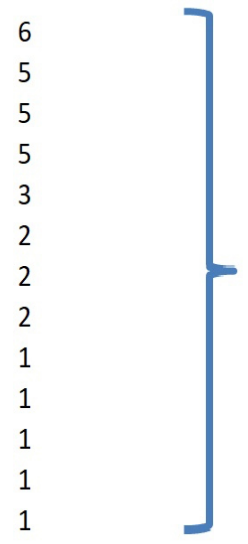

Trauma : $35(33,3 \%)$

2

2

1

1

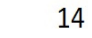

3

3

1

1

3

1

1

1

$+$
Hand and Finger

Injuries: $27(25,7 \%)$

2

1

1

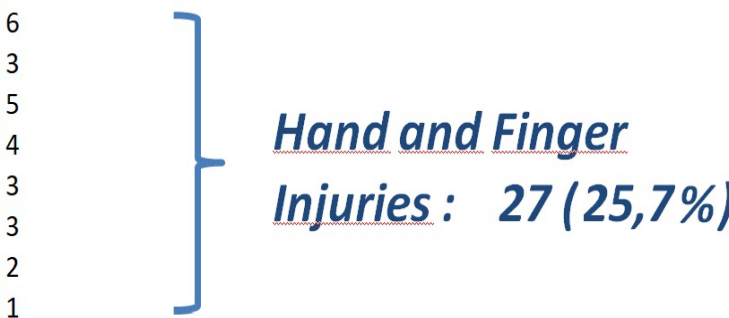

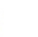

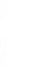

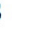

4

- Oncology: 15 (14.3\%)
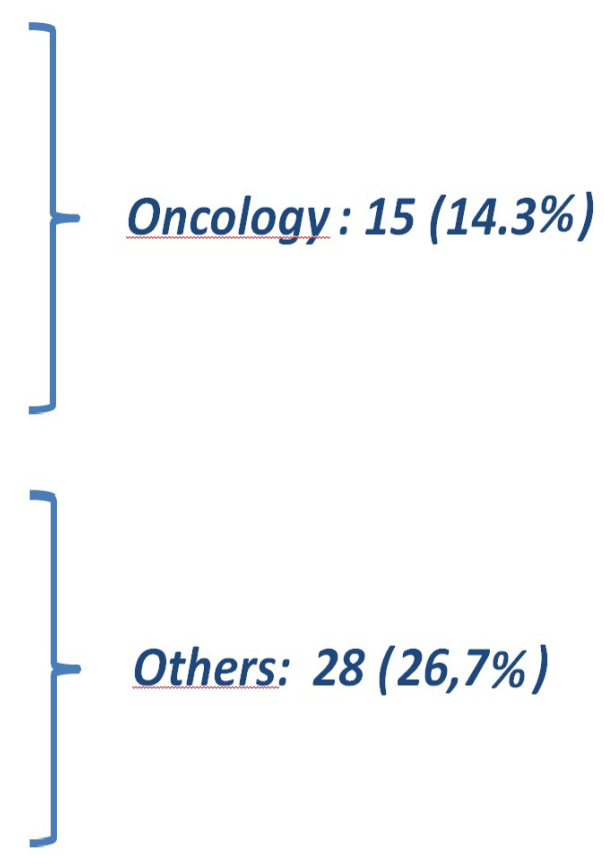

Total Number of Cases: 105 


\begin{tabular}{|c|c|c|}
\hline & March 17 - April 242019 & March 17 - April 242020 \\
\hline Trauma & $84(19,3 \%)$ & $35(33,3 \%)$ \\
\hline Arthroplasty & $55(12,6 \%)$ & 0 \\
\hline Hand and finger injuries & $52(11,9 \%)$ & $27(25,7 \%)$ \\
\hline Total & 436 & 105 \\
\hline
\end{tabular}

Table 3: Number of patients referred for consultation from the emergency departments to the orthopedics and traumatology department in the periods of March 17 - April 24, 2019 and March 17 - April 24, 2020

March 17 - April 242019

Adult emergency

235

Pediatric emergency

Total
March 17 - April 242020

105

69

174 from the emergency departments. It is thought that there is a decrease in trauma cases that will cause emergency admission due to lockdown restrictions applied because of the pandemic.

\section{COVID-19 Case Management in Orthopedics and}

\section{Traumatology Department}

Of the 105 surgeries performed between March 17 and April 24, 2020, 7 were accepted as "emergent" surgery and the patients were operated on by being accepted possible COVID positive without waiting for the PCR results. Of these cases, 3 were finger replantation, 3 were septic arthritis, and 1 was open tibia fracture. After the operation, the results of screening tests were followed, and isolation was applied to the patients and their relatives in the orthopedic service during this time. The PCR results of the said patients were negative and no COVID symptoms were observed during the follow-up period in the department.

In the period between March 17 and April 24, 2020, two of the patients who were admitted to the orthopedics department with the operation plan from the emergency department were found to be COVID positive during the screening test. Both patients were asymptomatic and there were no findings such as high fever, cough, and dyspnea. The patients were transferred to the COVID service and continued to be followed there. One of the two patients had a trimalleolar fracture and a short leg splint was applied. Before the operation, edema was expected to decrease, and elevation and cold application were recommended. Since the effect of NSAIDs on COVID pathogenesis could not be established precisely, the infection committee did not want NSAID to be used as the antiedema treatment (6). The patient, whose edema regressed late, was operated on the $10^{\text {th }}$ day of hospital admission with attention to personal protective measures. An operation was planned for the other patient due to metacarpal fracture and the patient was transferred to the COVID service when the PCR result was positive. The patient was operated on the $7^{\text {th }}$ day of hospital admission because the control PCR tests seen after the treatment were negative twice with an interval of 24 hours.

COVID was detected in two patients who were operated by us before March 11, when the first cases seen in Turkey, and could not be discharged because their treatments were not completed. Neither patient has a history of contact. During their follow-up in the department, a screening test was performed upon detecting high body temperature, and when the result was positive, patients were referred to infectious diseases for consultation and transferred to the COVID service. In the screening, the companions of both patients were COVID positive and it was highly likely that the patients were infected with COVID through the companions.

Screening tests were carried out on healthcare personnel in contact with COVID-positive patients. PCR was found positive in only one nurse during the screenings, and the nurse was hospitalized and treated by the infection committee. Posttreatment control tests were negative, and the nurse returned to her duty after two weeks of isolation at home.

\section{Study Limitations}

The main limitation of this study is that the time period was short. We conveyed our observations and experiences about early period of pandemic. A study which has a longer time period may better explain the effect of the pandemic on orthopedic practices. 


\section{Conclusion}

In the 6-week period from the official declaration of the first case in Turkey up to the descending trend of the number of active cases, we, as the orthopedics and traumatology clinic, conveyed our observations and experiences to shed light on studies in the future. The COVID-19 pandemic deeply influenced the daily life and working practice of the orthopedics and traumatology community, as in the rest of the world. In this process, orthopedists, like other physicians, have gained valuable experiences that they will always remember in their professional lives. It is important to create a management organizational chart during crisis periods such as pandemic and to implement the measures to be taken immediately. It is important to manage the process from a single center, create job descriptions within the hospital according to changing conditions, and involve the staff in the process by informing them.

\section{Ethics}

Ethics Committee Approval: The study protocol received Institutional Review Board approval (No: i7-428-20).

Informed Consent: Retrospective study.

Peer-review: Externally and internally peer-reviewed.

\section{Authorship Contributions}

Surgical and Medical Practices: M.O.K., M.K., K.B., M.A., H.K., A.M., R.A., E.A.Ö., B.E., H.Y.Y., H.K., Concept: M.O. K., M.Ö.,
Design: M.O.K., M.Ö., Data Collection or Processing: M.O.K., M.Ö., Analysis or Interpretation: M.O.K., M.Ö., Literature Search: M.Ö., Writing: M.O.K., M.K., M.Ö.

Conflict of Interest: No conflict of interest was declared by the authors.

Financial Disclosure: The authors declared that this study received no financial support.

\section{References}

1. Zhu N, Zhang D, Wang $W$, et al. A novel coronavirus from patients with pneumonia in China, 2019. N Engl J Med. 2020;382:727-733.

2. Guo X, Wang J, Hu D, et al. Survey of COVID-19 disease among orthopaedic surgeons in Wuhan, People's Republic of China. J Bone Joint Surg Am. 2020;102:847-854 doi: 10.2106/JBJS.20.00417.

3. Catrin S, Zaid A, Niamh O. et al. World Health Organization declares global emergency: a review of the 2019 novel coronavirus (COVID-19). Int. J. Surg. 2020;77:217 doi: 10.1016/j.ijsu.2020.02.034.

4. The official website of the Republic of Turkey Ministry of Health, https:// COVID19.saglik.gov.tr/ [accessed 6 October 2020]

5. Ankara University Faculty of Medicine Action Plan for Pandemic COViD-19 (SARS CoV-2). 2020 http://hastane.ankara.edu.tr/COVID-19-pandemieylem-plani/ [accessed 6 October 2020]

6. Little P. Non-steroidal Anti-inflamatory drugs and COVID-19. 2020 March 27. BMJ 2020;368:m1185 doi: 10.1136/bmj.m1185. 